\title{
Antiulcer and Blood-Boosting Activities of Feeds Supplemented with Trametes versicolor from Nigeria
}

Segun Gbolagade Jonathan ${ }^{1 *}$, Francis Omeonu ${ }^{1}$, Adeola Temitope Salami ${ }^{2}$, John Chikwem ${ }^{3}$ Idayat Titilayo Gbadamosi ${ }^{4}$, Michael Asemoloye ${ }^{5}$, and Daniel Ayandiran Aina ${ }^{6}$

${ }^{1}$ Mycology \& Applied Microbiology Group, Department of Botany, University of Ibadan. Nigeria

${ }^{2}$ Gastrointestinal Secretion and Inflammatory Research Unit, Department of Physiology, University of Ibadan, Ibadan, Nigeria

${ }^{3}$ Department of Biology, Lincoln University, 1570 Baltimore Pike, Pennsylvania, USA

${ }^{4}$ EthnoBotany \& Economic Botany Unit, Department of Botany, University of Ibadan Nigeria

${ }^{3}$ School of Pharmaceutical Science and Technology, Health Science Platform, Tianjin University Nankai District, Tianjin China

${ }^{6}$ Department of Microbiology, Babcock University, Ilisan Remo, Ogun State, Nigeria

DOI: $10.36347 /$ sajb.2020.v08i09.005

| Received: 10.08 .2020 | Accepted: 18.09 .2020 | Published: 25.09 .2020

*Corresponding author: Segun Gbolagade Jonathan

Abstract

Original Research Article

Antiulcer and blood-boosting activities of feeds supplemented with Trametes versicolar (Tv) in Wistar rats (Rattus norvegicus) were studied. Haematological studies and antiulcer biochemical analysis were carried out on the rats using standard methods. Data were presented as Mean \pm SEM, analyzed using two-way ANOVA and $p \leq 0.05$ was significantly different in all the variables. Haematological parameters were not significantly different across all $T v$ treatments when compared with the control $(\mathrm{CN})$. There were also significant differences in values obtained for gastric ulcer inhibition, nitric oxide, mucin, sulfhydryl, and $\mathrm{H}^{+} / \mathrm{K}^{+}$-ATPase. $T v$ treatment groups also differed when compared with ulcerated untreated control (CU). The pathological changes detected from histological studies on the stomach tissues showed inhibition of ulcers. $T v$ treatment groups demonstrated blood boosting and antiulcer activity through synergistic activities of mucin, $\mathrm{H}^{+} / \mathrm{K}^{+}$ATPase activity, and antioxidant mechanism. The implications of these observations are discussed.

Keywords: Tramates versicolor, Antioxidant, Haematology, and Ulcer inhibition.

Copyright @ 2020: This is an open-access article distributed under the terms of the Creative Commons Attribution license which permits unrestricted use, distribution, and reproduction in any medium for non-commercial use (NonCommercial, or CC-BY-NC) provided the original author and source are credited

\section{INTRODUCTION}

Ascomycetes and Basidiomycetes are major classes of higher fungi which form reproductive structures known as fruit bodies or basidiocarps [1]. Many higher fungi have been used in different countries of the world as sources of protein, dietary fibre, unsaturated lipids and different mineral elements [2-4]. Nigerian higher fungi have been reported to possess different medicinal properties [5-11]. Therapeutic values of fungi are directly linked to their possession of phytochemicals and bioactive compounds [12, 13]. These bioactive molecules could be extracted from edible, inedible and poisonous fungal species and characterized. In developing countries especially Nigeria, the medicinal uses and quest for new health and nutritional supplements from fungi have been exploited by scientists and indigenous people. Medicinal fungi have been used in the management of several diseases [14-16]. Problems related to the use of standard drugs are being addressed by the advocacy for the exploitation and use of herbal products as alternatives.
Different fungi have been used from ancient times, by traditional healers from Asia, Africa, America and Europe. Traditional medical practitioners in South-Western Nigeria usually prepare hot water extracts of fungi with other medicinal plants, or they may use local gin for the extraction of these fungi $[5,8]$.

Trametes versicolor is a polypore fungus. It is also known as Polyporus versicolor or Coriolus versicolor. This fungus has been reported as possessing antioxidant, immunomodulatory and anti-inflammatory [17, 18], anticancer [19], antimicrobial [11], and prebiotic [19] properties.

Blood is the transport medium in the body of all mammals. Anything that affects blood, usually affects the entire body in relation to growth, health, body maintenance, and reproduction. However, nutritional factors usually influence blood status of any animal [20, 21].Blood parameter assessment can be used to determine the effects of foreign materials such as medicinal herbs. 
Gastric Ulcer (GU) is known as an ulcer of the stomach and is defined as sub-mucosal or deeper erosion of normal gastric mucosa. Peptic Ulcer Disease (PUD) is predominantly induced by Helicobacter pylori. Non-steroidal anti-inflammatory medicines have been linked to the increased secretion of gastric acids. Anxiety, smoking, spicy foods and dietary deficiencies are the other factors. Peptic ulcer disease risks may include internal bleeding, gastro-intestinal blockage, perforation, and peptic ulcer refractory $[21,22]$. Peptic ulcer disease is significant worldwide, affecting $4 \%$ of the total population. There were 327,000 deaths from PUD in 1990 and 301,000 deaths in 2013 [22]. Every year, 4 million people throughout the world are affected by PUD. Accordingly, conventional medicine manages ulcers with proton pump inhibitors (PPIs), $\mathrm{H}_{2}$ receptor antagonists, antacids, antibiotics, and mucosal protection agents [23]. Nevertheless, there are reports of negative effects and long-term recurrences from these medications. Consequently, people are exploring other alternatives, including natural remedies.

Macrofungi from Nigeria have been reported of possessing secondary metabolites, which has made them to be reservoirs of useful bioactive compounds with valuable therapeutic values $[1,12,16]$. However, there is a dearth of information on the haematinic or antiulcer properties of Trametes versicolor. The purpose of this study was to examine the antiulcer and blood boosting activities of Trametes versicolor from Ibadan, southwestern, Nigeria.

\section{MATERIALS AND METHODS}

Fresh fruit bodies of wild Trametes versicolor were collected during the rainy season (August-September, 2017) from University of Ibadan Botanical Gardens, Ibadan $\left(7.3775^{\circ} \mathrm{N}, 3.9470^{\circ} \mathrm{E}\right)$ in Oyo State, South-West Nigeria. This preliminary identity was validated and further subjected to the standard descriptions of Ostry et al. [24]. The fungal samples were air-dried, powdered and preserved for future use in an air-tight amber bottle, and refrigerated at $4^{\circ} \mathrm{C}$.

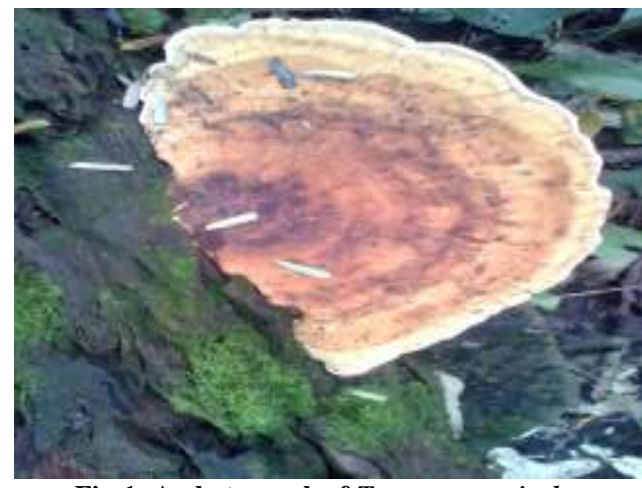

Fig-1: A photograph of Tramates versicolor

\section{Rat Experiments}

Thirty five Wistar rats $(100-110 \mathrm{~g} ; \mathrm{n}=7)$ were divided into five groups thus: Groups 1- (un-ulcerated normal feed $(\mathrm{CN}) ; 2$ - (ulcerated not treated (CU); 3- (20 $\mathrm{mg} / \mathrm{kg}$ of cimetidine $(\mathrm{Cm}) ; 4-(20 \%$ of $T v)$ and $5-(40 \%$ of $T v$ ) for days 7 and 14 respectively. Full haematological analysis was carried out on the rats at the end of each experimental day. The animals had free access to their normal feeds for the control experiments and were pretreated with $T v$ and cimetidine for 7 and 14 days respectively with water ad libitum throughout the experiment. They were then fasted for $24 \mathrm{hrs}$ prior to the administration of indomethacin and sacrificed after 4 hours. The stomach of each rat was excised, weighed, and graded for ulceration. Animal experiments were performed in line with Experimental Animal Care and Use Guidelines of the National Institute of Health (Pub No. 85-23, revised 1985). Biochemical and histological studies were carried out on the excised stomach tissues using standard methods.

\section{Determination of Full Blood Cell Count}

The Dacie and Lewis [25] methods were used for haematological research in the analysis of blood.

\section{Macroscopic Assessment Scoring of Ulcer}

Inas et al. [26] method was used for indomethacin-induced ulceration while gastric ulceration was assessed using Elegbe and Bamigbose [27] established scoring technique.

\section{Histopathological Studies}

For the histological studies, the method Elegbe and Bamigbose [27] was used. Biochemical determination of Lipid peroxidation, Nitric oxide (NO), Sulfhydryl content, Mucosal Hydrogen-peroxide $\left(\mathrm{H}_{2} \mathrm{O}_{2}\right)$, Total protein concentration, Hydrogen/Potassium anti-pump activities, and Mucin content.

The lipid peroxidation was calculated by the method of Varshney and Kale [28], and the concentration of nitrite in the supernatant was measured as an NO production indicator detected by the Griess reaction [17]. Sulfhydryl levels and the Hydrogen peroxide $\left(\mathrm{H}_{2} \mathrm{O}_{2}\right)$ tissue activity was carried out using the principles of Elegbe and Bamigbose [27]. The protein concentrations of the various samples were estimated using the Biuret process, as defined by Elegbe and Bamigbose [27], with a slight modification; and the determination of Hydrogen/Potassium anti-pump activities was carried out using the method Ronner et al. [29], as updated by Bewaji et al. [30]. Determination of mucin content was carried out by using the method of Bewaji et al. [30]. 
STATISTICAL ANALYSIS

Data were expressed as Mean \pm SEM, analyzed using two-way ANOVA and $\mathrm{p} \leq 0.05$ was significant.

\section{RESULTS}

Table-1: Influence of Trametes versicolar supplemented diets on packed cell volume, erythrocyte sedimentary rate, recticulocyte, haemoglobin, and red blood cell and platelets counts

\begin{tabular}{|c|c|c|c|c|c|c|c|c|c|c|c|c|}
\hline \multirow[t]{2}{*}{ Groups } & \multicolumn{2}{|c|}{$\operatorname{PCV}(\%)$} & \multicolumn{2}{|c|}{$\begin{array}{c}\text { ESR } \\
(\mathrm{mm} / \mathrm{hr})\end{array}$} & \multicolumn{2}{|c|}{$\begin{array}{l}\text { RECTIC } \\
\left(\times 10^{9} / \mathrm{L}\right) \\
\end{array}$} & \multicolumn{2}{|c|}{$\begin{array}{c}\text { HB } \\
(\mathrm{g} / \mathrm{dl})\end{array}$} & \multicolumn{2}{|c|}{$\begin{array}{c}\text { RBC } \\
\left(\mathbf{x 1 0}^{12} / \mathrm{L}\right)\end{array}$} & \multicolumn{2}{|c|}{$\begin{array}{c}\text { PLATELETS } \\
\left(\times 10^{9} / \mathrm{L}\right)\end{array}$} \\
\hline & Day 7 & Day14 & Day 7 & Day14 & Day 7 & Day14 & Day 7 & Day14 & Day 7 & Day14 & Day 7 & Day14 \\
\hline $\mathrm{CN}$ & $\begin{array}{c}41 \pm 0 \\
5\end{array}$ & $\begin{array}{c}49.3 \pm 2 \\
.3\end{array}$ & $1.13 \pm 0.7$ & $\begin{array}{c}1.43 \pm 0 \\
.07\end{array}$ & $2.4 \pm 0.2$ & $3.3 \pm 0.4$ & $\begin{array}{c}13.8 \pm \\
0.4\end{array}$ & $\begin{array}{c}14.77 \pm \\
0.12\end{array}$ & $\begin{array}{c}7.23 \pm 0 \\
.4\end{array}$ & $\begin{array}{c}7.49 \pm 0 . \\
15\end{array}$ & $\begin{array}{c}144333 \\
\pm 15\end{array}$ & $\begin{array}{c}4666 \pm 5 \\
0\end{array}$ \\
\hline $20 \mathrm{TV}$ & $\begin{array}{c}44 \pm 1 \\
53\end{array}$ & $\begin{array}{c}51.3 \pm 2 \\
.76\end{array}$ & $1.23 \pm 0.2$ & $\begin{array}{c}1.27 \pm 0 \\
.08\end{array}$ & $2.7 \pm 0.1$ & $3.3 \pm 0.3$ & $\begin{array}{c}14.6 \pm \\
0.7\end{array}$ & $\begin{array}{c}16.9 \pm 0 \\
.3\end{array}$ & $\begin{array}{c}7.4 \pm 0 . \\
4\end{array}$ & $\begin{array}{c}8.37 \pm 0 . \\
3\end{array}$ & $\begin{array}{c}127000 \\
\pm 10\end{array}$ & $\begin{array}{c}123666 \\
\pm 7\end{array}$ \\
\hline $40 \mathrm{TV}$ & $\begin{array}{c}43.3 \pm \\
0.67\end{array}$ & $50 \pm 0.0$ & $1.9 \pm 0.7$ & $\begin{array}{c}1.33 \pm 0 \\
.03\end{array}$ & $2.5 \pm 0.6$ & $\begin{array}{c}3.03 \pm 0 . \\
1\end{array}$ & $\begin{array}{c}14.8 \pm \\
0.8\end{array}$ & $\begin{array}{c}16.4 \pm 0 \\
.2\end{array}$ & $\begin{array}{c}7.4 \pm 0 . \\
6\end{array}$ & $\begin{array}{c}8.65 \pm 0 . \\
01\end{array}$ & $\begin{array}{c}108666 \\
\pm 15\end{array}$ & $\begin{array}{c}97666 \pm \\
7\end{array}$ \\
\hline
\end{tabular}

Values are expressed as Mean \pm SEM. $(\mathrm{n}=3)$. All values were not significantly different from control normal $(\mathrm{CN})$ at $\mathrm{p}<0.05 .20 T v=20 \%$ w/w of Tramates versicolar in feed, $40 T v=40 \%$ w/wof Tramates versicolar in feed, Control normal (CN),-control group not ulcer-induced.

Influence of Trametes versicolor supplemented diets on packed cell volume, erythrocyte sedimentary rate, reticulocyte, haemoglobin, red blood cell, and platelet counts on Wistar rat is shown in Table 1. On both days of treatments, no significant differences in the above hematological variables were observed with $40 T v$ and $20 T v$ when compared with $\mathrm{CN}$. Haematological analysis was performed on the effect of Trametes versicolor supplemented diets on Wistar rats, and their results showed no significant effects.

Table-2: Influence of Tramates vesicolor supplemented diets on white blood cell, lymphocyte, and neutrophils, monocyte, and eosinophils counts in wistar rat

\begin{tabular}{|c|c|c|c|c|c|c|c|c|c|c|}
\hline \multirow[t]{2}{*}{ Group } & \multicolumn{2}{|c|}{$\begin{array}{l}\text { WHITE BLOOD CELL( } \\
\left.10^{6} / \mu \mathrm{L}\right) \\
\end{array}$} & \multicolumn{2}{|c|}{$\begin{array}{l}\text { LYMPHOCYTES } \\
\left(1^{3} / \mu \mathrm{L}\right)\end{array}$} & \multicolumn{2}{|c|}{$\begin{array}{l}\text { NEUTROPHILS } \\
\left(10^{3} / \mu \mathrm{L}\right)\end{array}$} & \multicolumn{2}{|c|}{$\begin{array}{c}\text { MONOCYTE } \\
\left(10^{3} / \mu \mathrm{L}\right)\end{array}$} & \multicolumn{2}{|c|}{$\begin{array}{c}\text { EOSINOPHILS } \\
\left(10^{3} / \mu \mathrm{L}\right)\end{array}$} \\
\hline & Day 7 & Day14 & Day 7 & Day14 & Day 7 & Day14 & Day 7 & Day14 & Day 7 & Day14 \\
\hline & & & & 77. & & & $1.3 \pm 0.33$ & & 0.88 & 0.33 \\
\hline $20 \mathrm{Tv}$ & & & $72.7 \pm 4.3$ & & $25 \pm 1.5$ & $15.7 \pm 0.5$ & $1 \pm 00$ & & $1.33 \pm 0.33$ & $0.67 \pm 0.06$ \\
\hline $40 \mathrm{Tv}$ & $5067 \pm 33$ & $3416.7 \pm 25$ & $68.3 \pm 5.7$ & $80.7 \pm 0.3$ & $28 \pm 3.7$ & $17 \pm 0.5$ & $1.33 \pm 0.33$ & $2.33 \pm 0.67$ & $33 \pm 0.67$ & $0.67 \pm 0.04$ \\
\hline
\end{tabular}

Values are expressed as Mean \pm SEM. $(\mathrm{n}=3)$. All values were not significantly different from control normal $(\mathrm{CN})$ at $\mathrm{p}<0.05 .20 T v=20 \%$

$\mathrm{w} / \mathrm{w}$ of Tramates versicolar in feed, $40 T v=40 \% \mathrm{w} / \mathrm{wof}$ Tramates versicolar in feed, Control normal $(\mathrm{CN})$, -control group not ulcer-induced

Influence of Trametes versicolor supplemented diets on white blood cells (WBC), lymphocytes, neutrophils, monocytes, and eosinophils counts are shown in Table 2. No observable differences in the haematological variables were noticed with $40 T v$ and $20 T v$ with $\mathrm{CN}$ on both days of treatments.

Table-3: Influence of Trametes versicolar supplemented diets on Albumin, Globulin, Blood urea nitrogen, and Creatinine on rat

\begin{tabular}{|l|l|l|l|l|l|l|l|l|}
\hline \multirow{2}{*}{ Groups } & \multicolumn{2}{|l|}{$\begin{array}{l}\text { ALBUMIN } \\
\text { (g/dL) }\end{array}$} & \multicolumn{2}{l|}{$\begin{array}{l}\text { GLOBULIN } \\
\text { (g/dL) }\end{array}$} & \multicolumn{2}{l|}{$\begin{array}{l}\text { BUN } \\
\text { (g/dL) }\end{array}$} \\
\cline { 2 - 9 } & Day 7 & Day14 & Day 7 & Day14 & Day 7 & Day14 & Day 7 & Day14 \\
\hline CN & $2.87 \pm 0.3$ & $2.93 \pm 0.18$ & $4.5 \pm 0.2$ & $4.17 \pm 0.3$ & $17.27 \pm 0.35$ & $16.67 \pm 0.18$ & $0.77 \pm 0.03$ & $0.83 \pm 0.09$ \\
\hline $20 \mathrm{Tv}$ & $2.9 \pm 0.25$ & $3.67 \pm 1.2$ & $4.67 \pm 0.08$ & $3.87 \pm 0.07$ & $17.7 \pm 0.15$ & $17.77 \pm 0.12$ & $0.73 \pm 0.07$ & $0.87 \pm 0.07$ \\
\hline $40 \mathrm{Tv}$ & $3.1 \pm 0.06$ & $3.27 \pm 0.3$ & $4.53 \pm 0.07$ & $4.77 \pm 0.13$ & $17.53 \pm 0.09$ & $18.4 \pm 0.12$ & $0.8 \pm 0$ & $1 \pm 0.12$ \\
\hline
\end{tabular}

Values are expressed as Mean \pm SEM. $(\mathrm{n}=3)$. All values were not significantly different from control normal $(\mathrm{CN})$ at $\mathrm{p}<0.05 .20 T v=20 \%$ w/w of Tramates versicolar in feed, $40 T v=40 \%$ w/wof Tramates versicolar in feed, Control normal $(\mathrm{CN})$,-control group not ulcer-induced

Influence of Trametes versicolar supplemented diets on Albumin, Globulin, Blood urea nitrogen, and Creatinine on the rats is shown in Table 3. It was observed that on both days of treatments, there were no significant effects in the above serum biochemical variables with $20 T v$ and $40 T v$ when compared with $\mathrm{CN}$. 
Table-4: Influence of Trametes versicolor supplemented diets on ulcer score, ulcer index and ulcer percentage inhibition. of Indomethacin- Induced Gastric Ulcerated rats.

\begin{tabular}{|c|c|c|c|c|c|c|}
\hline \multirow[t]{2}{*}{ Treatment } & \multicolumn{2}{|c|}{ Mean ulcer score $($ mean \pm SEM $)$} & \multicolumn{2}{|c|}{ Ulcer index $\left(\mathrm{mm}^{2}\right)$} & \multicolumn{2}{|c|}{ Percentage inhibition (\%) } \\
\hline & Day 7 & Day 14 & Day 7 & Day 14 & Day 7 & Day 14 \\
\hline $\mathrm{CN}$ & $0.0 \pm 0$ & $0.0 \pm 0$ & 0.0 & 0.0 & 0 & 0 \\
\hline $\mathrm{CU}$ & $6.0 \pm 2.3$ & $6.0 \pm 2.3$ & 0.18 & 0.18 & 0 & 0 \\
\hline $\mathrm{Cm}$ & $3.5 \pm 1.2$ & $1.83 \pm 0.4$ & 0.11 & 0.06 & 41.67 & 69.44 \\
\hline $20 \mathrm{Tv}$ & $3.5 \pm 1.2$ & $2.17 \pm 0.5$ & 0.11 & 0.07 & 41.67 & 63.89 \\
\hline $40 \mathrm{Tv}$ & $5.67 \pm 1.6$ & $3.67 \pm 1.03$ & 0.17 & 0.11 & 5.56 & 41.67 \\
\hline
\end{tabular}

Values were expressed as Mean \pm SEM. $(\mathrm{n}=3) .20 T v=20 \% \mathrm{w} / \mathrm{w}$ of Tramates versicolar in feed, $40 T v=40 \% \mathrm{w} / \mathrm{w}$ of Tramates versicolor in feed, Control normal $(\mathrm{CN})$,-control group not ulcer-induced. Ulcer untreated control (CU). (Cm)- Control treated with $20 \mathrm{mg} / \mathrm{kg}$ of cimetidine

Influence of Trametes versicolor supplemented diets on ulcer score, ulcer index, and ulcer percentage inhibition of Indomethacin- Induced Gastric Ulcerated is presented in Table 4.

It was observed that both treatments of $20 \% \mathrm{w} / \mathrm{w}$ Tramates versicolor $(20 T \mathrm{v})$ and $40 \% \mathrm{w} / \mathrm{w}$
Tramates versicolor (40Tv) significantly increased in ulcer percentage inhibition by day 7 and day 14 when compared to CU. However, the highest inhibition of ulcer percentage was observed after day 14 for both $20 T \mathrm{v}$ and $40 T v$

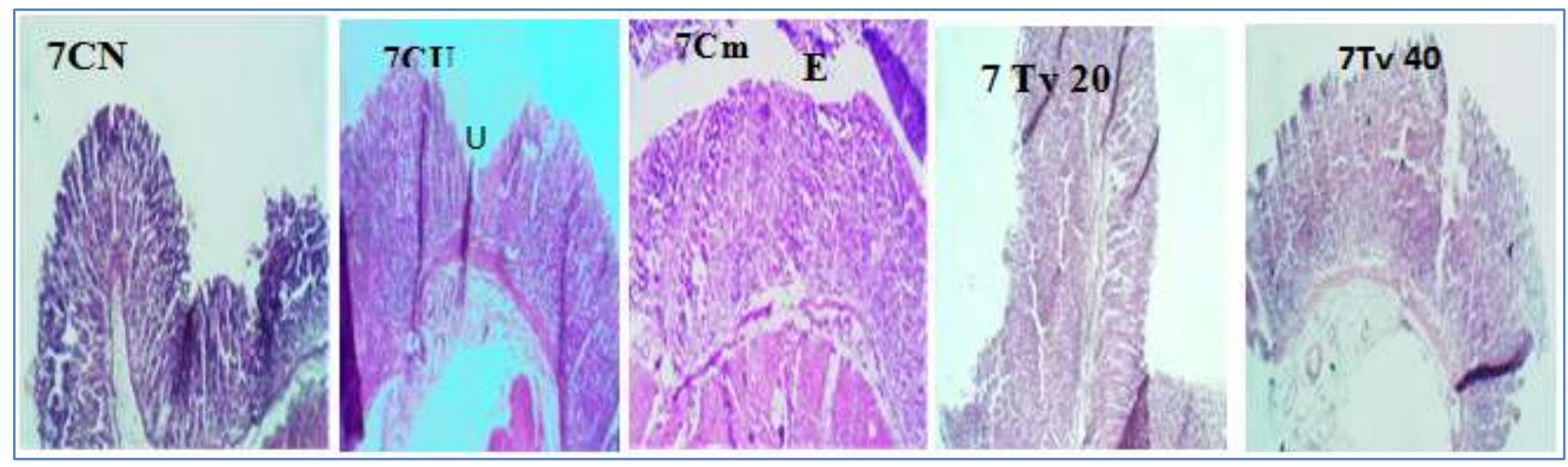

Plate-1: Photomicrograph of stomach section Day 7 stained by Haematoxylin and Eosin stain MAG. X100) showing; 7CN: There is no observable lesion in the gastric mucosa, $7 \mathrm{CU}$ : There is marked ulceration, necrosis of chief cells and inflammation in the gastric mucosa $(\mathrm{U})$, 7Cm: There is erosion of the gastric mucosa (E), $7 \mathrm{Tv} 20$ : There is necrosis and loss of gastric mucous cells, $7 \mathrm{Tv} 40$ : There is no observable lesion

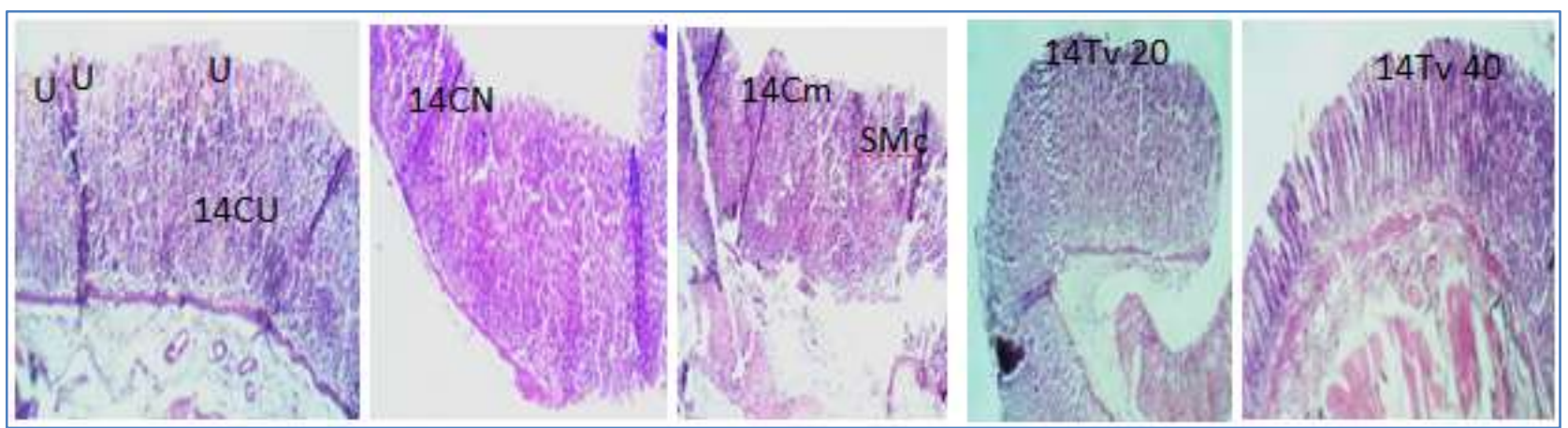

Plate-2: Photomicrograph of stomach section (Day 14 stained by Haematoxylin and Eosin stain MAG. X 100) showing; 14CU: There is ulceration of the mucosa with hemorrhagic exudate $(U), 14 \mathrm{CN}$ : There is no observable lesion, $14 \mathrm{Cm}$ : There is loss of surface mucous cells ( SMc), 14Tv 20: There is no observable lesion, 14Tv 40: There is no observable lesion. 


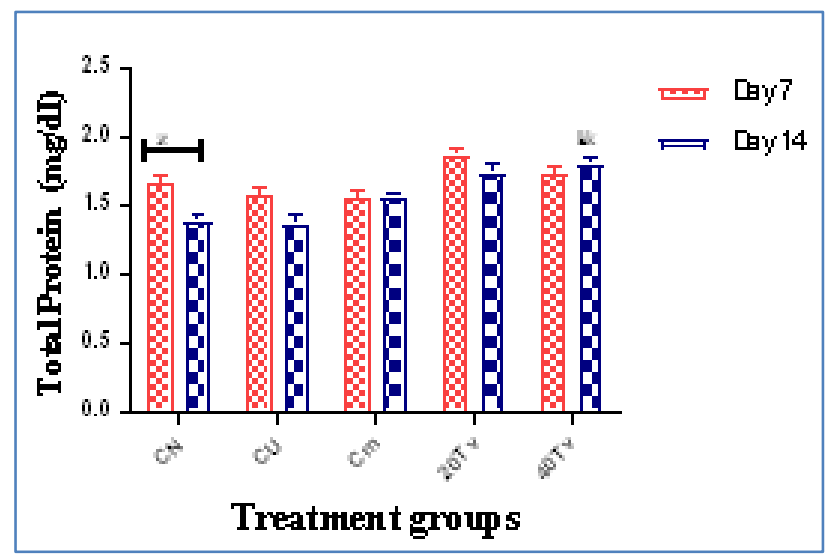

Fig-2: Influence of Trametes versicolor supplemented diets on total protein of Indomethacin- Inducd Gastric Ulcerated rats for 7 and 14 day exposure periods

Figure 2, shows the influence of 20Tv and 40Tv diets on the total protein content of IndomethacinInduced Gastric Ulcerated rats for exposure periods of 7 and 14 days. On days 7 and 14 of treatment, no significant increases (JP <0.05) were observed with treatment groups formulated with $20 \mathrm{Tv}$ and 40Tv except $40 \mathrm{Tv}\left({ }^{\mathrm{kkk}} \mathrm{p}<0.001\right)$ after day 14 of treatment as compared to CU.

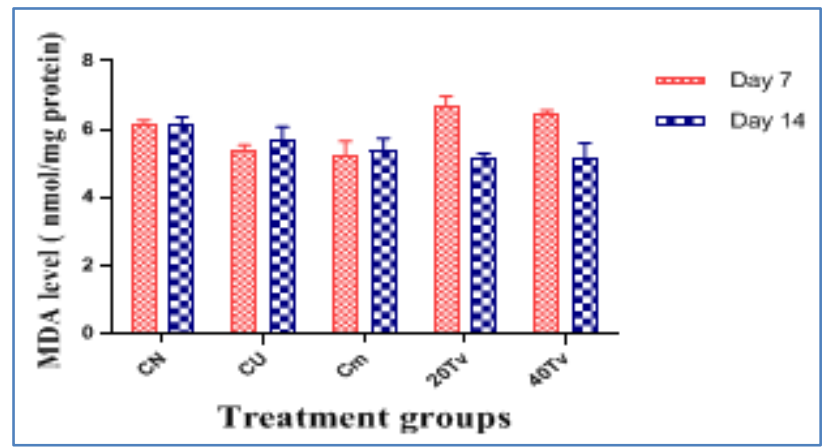

Fig-3: Influence of Trametes versicolor supplemented diets on Malondialdehyde (MDA) Level of Indomethacin- Inducd Gastric Ulcerated rats for 7 and 14 days exposure periods

No significant differences were observed on MDA with $20 T v$ and $40 T v$ on days 7 and 14 . No significant decrease was found with $20 T v$ and $40 T v$ relative to $\mathrm{CU}$ for the contrast between days 7 and 14 treatments.

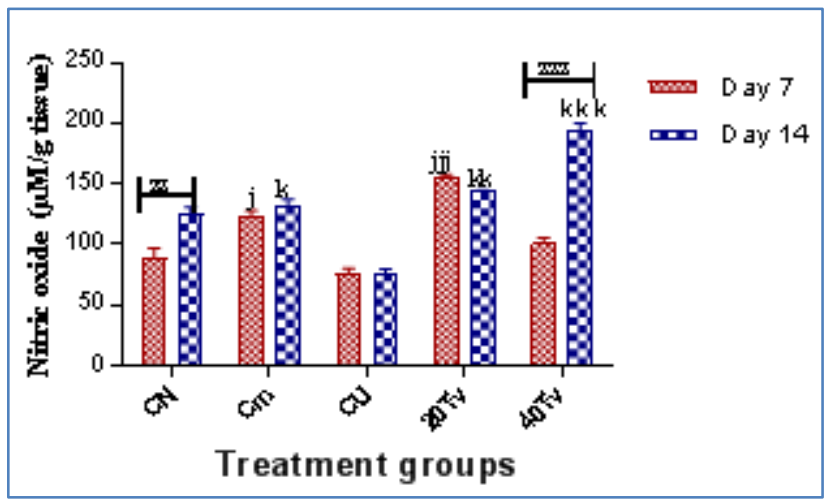

Fig-4: Inflence of Trametes versicolor supplemented diets on Nitric Oxide (NO) Content of indomethacin induced ulcer in rats for 7 and 14 day exposure periods.

On day 7, only supplemented group of $20 T v$ increased significantly compared to CU. For day 14 , the nitric oxide content of both $20 T v$ and $40 T v$ increased significantly as compared to $\mathrm{CU}$; however, significant increase was only observed with $40 T v$ treatment when comparing 7 and 14 day treatments. 


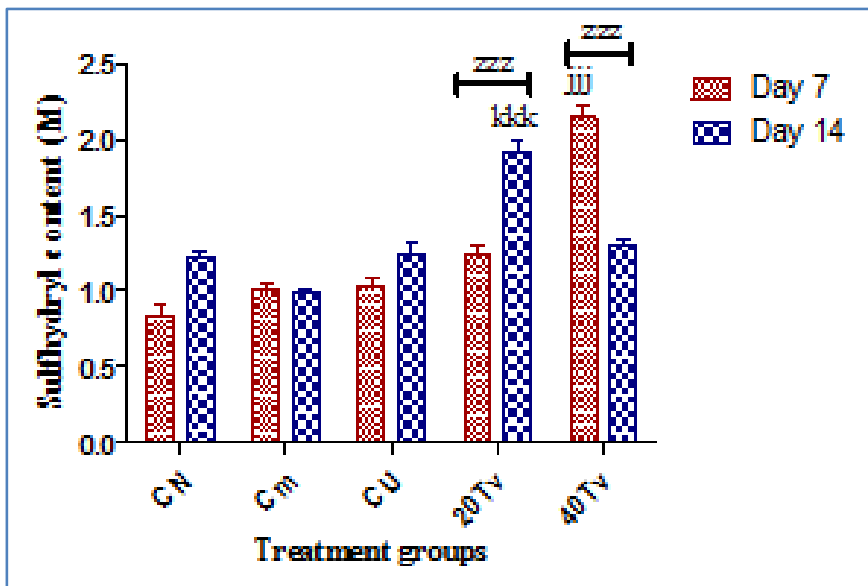

Fig-5: Influence of Trametes versicolor supplemented diets on sulfhydryl content of indomethacin induced ulcerin rats for 7, and 14 days exposure periods

On day 7 , a significant increase $\left(\mathrm{jij}^{\mathrm{j}} \mathrm{p}<0.001\right)$ was only observed with $40 T v$ while a significant increase $\left({ }^{\mathrm{kkk}} \mathrm{p}<0.001\right)$ was observed with $20 T v$ on day 14 when compared with CU. Comparing day 7 and day 14, significant differences $\left({ }^{\mathrm{zzZ}} \mathrm{p}<0.001\right)$ were observed with both $20 T v$ and $40 T v$.

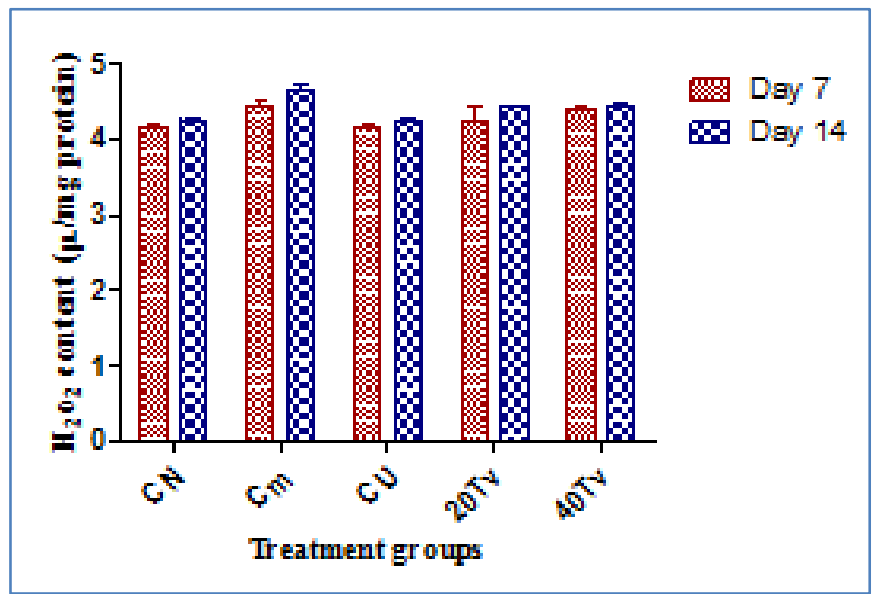

Fig-6: Influence of Trametes versicolor supplemented diets on hydrogen peroxide content of indomethacin induced ulcer in rats for 7 , and 14 days exposure periods

No significant increase was observed on days 7 and 14 in $\mathrm{CU}$ with $20 \mathrm{Tv}$ and $40 \mathrm{Tv}$ treatment groups.
Similarly, no significant differences with treatment days were noticed.

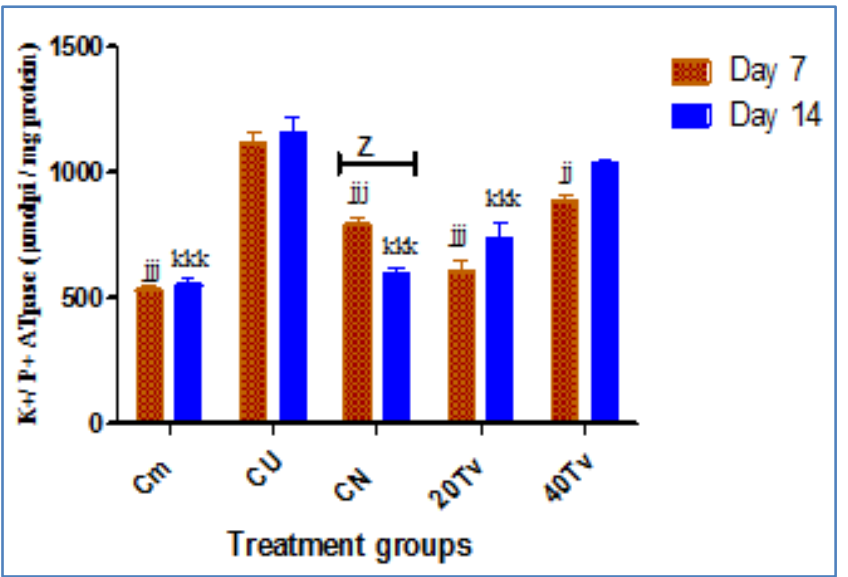

Fig-7: Influence of Trametes versicolor supplemented diets on Hydrogen Potassium pump activities of indomethacin induced ulcer in rats for 7 and 14 days exposure periods 
On days 7 and 14, all the treatment groups except 40Tv on day 14 showed significant decrease in $\mathrm{H}^{+} / \mathrm{K}^{+}$ATPase pump activity compared with CU.
Comparing day 7 and day 14 treatments, no significant difference $\left({ }^{\mathrm{z}} \mathrm{p}<0.05\right.$, ) was observed except with $\mathrm{CN}$ treatment groups.

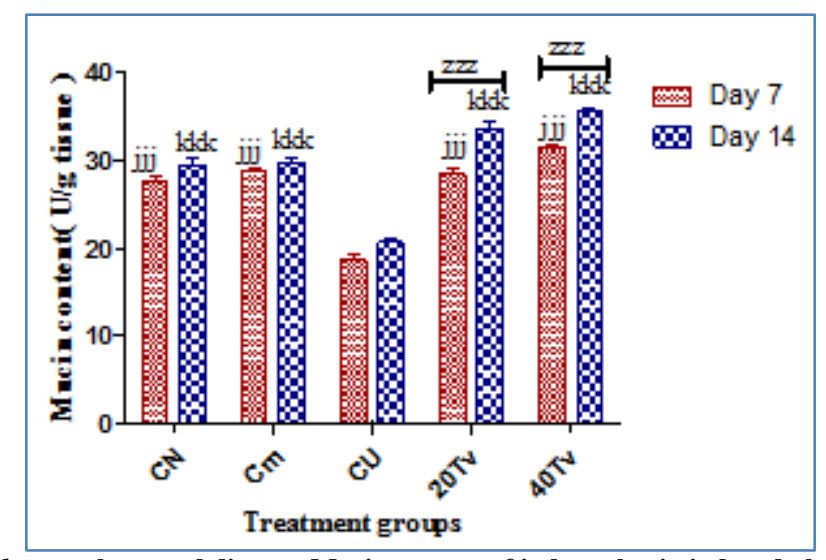

Fig-8: influence of Trametes versicolor supplemented diets on Mucin content of indomethacin induced ulcer in rats for 7 and 14 days exposure periods

Keys of significance: Following one-way Anova, ${ }^{\mathrm{j}} \mathrm{p}<0.05,{ }^{\mathrm{jj}} \mathrm{p}<0.01,{ }^{\mathrm{jjj}} \mathrm{p}<0.001$ at 7 days and ${ }^{\mathrm{k}} \mathrm{p}<$ $0.05,{ }^{\mathrm{kk}} \mathrm{p}<0.01,{ }^{\mathrm{kkk}} \mathrm{p}<0.001$ at 14 days compared with the corresponding ulcer untreated control (CU). Using two-way Anova, ${ }^{\mathrm{z}} \mathrm{p}<0.05,{ }^{\mathrm{zz}} \mathrm{p}<0.01,{ }^{\mathrm{zzz}} \mathrm{p}<0.001$, between 7 and 14 days' exposure periods. $20 T v=20 \%$ $\mathrm{w} / \mathrm{w}$ of Tramates versicolor in feed, $40 T v=40 \% \mathrm{w} / \mathrm{w}$ of Tramates versicolor in feed. Control normal (CN) -control group not ulcer-induced. Ulcer untreated control (CU). Control treated with $20 \mathrm{mg} / \mathrm{kg}$ of cimetidine $(\mathrm{Cm})$.

On days 7 and 14, a significant increase $\left({ }^{\mathrm{jjj}} \mathrm{p}<\right.$ 0.001 ) in Mucin contents was observed with $20 T v$ and $40 T v$; however, comparing days 7 and 14 treatments, both $20 T v$ and $40 T v$ showed significant increases $\left({ }^{\mathrm{zzz}} \mathrm{p}<\right.$ 0.001 ) in Mucin content on day 14.

\section{DISCUSSION}

From our results, Trametes versicolor supplemented diets do not affect erythropoiesis negatively. This observation is similar to the findings of Togun et al. [31], who reported that the increase in PCV in combination with the marginal increase in RBC shows more successful erythropoiesis in experimental rabbits. As observed in the results, increase in WBC observed on day 7 could be due to the adjustment of the rats to the formulated feed which was a foreign substance in their bodies while decrease observed in day14 treatment period revealed the immunomodulatory property of the supplemented feeds.

There were no major differences in neutrophils, lymphocytes, and monocytes seen, thus further confirming the results. Analysis of the renal and hepatic function was highly useful in screening for toxicity of medicine and herbal extracts, as both are essential to an organism's survival [32]. Trametes versicolor supplemented diets showed no sign of toxicity from the serum biochemical parameters indicating that the role of hepatocyte in rats will not be affected by sub-chronic feed intake. However, the existence of bioactive compounds known to have antioxidant and anti-inflammatory activities may be linked to their antiulcer property as observed with the percentage inhibition of the $T v$ supplemented diets [17]. This antiulcer property was further observed with the histological studies which showed healing features, such as the absence of observable lesions with the $T v$ treatments. The increase in total protein content observed may be due to the presence of high protein contents in mushrooms which is mostly needed during inflammation for cell regeneration and repair. This is in support of Jonathan et al. [33] findings, which reported that macro-fungi are highly rich in protein content.

The test of oxidative activities that used malondialdehyde assay as its marker showed that there was no breakdown of the lipid stores on the cell membrane due to the treatments. It also discloses the capability of the treatments to avoid an increase in the generation of free radicals that might have aggravated the induced gastric ulcer. The increase in NO as observed may have conferred antiulcer properties on the rats. Nitric oxide (NO) helps protect the integrity of the mucus membrane and stomach epithelium which helps to mediate gastric blood flow as a vasodilator and prevent the secretion of acids as well as stimulate the production of mucus and bicarbonate. It thereby gave protection to the gastrointestinal tract which is useful in gastric ulcer healing [34]. The increase in sulfhydryl level suggests gastro-protective effects of Trametes versicolor supplemented diets which is useful for the formation and maintenance of gastric mucus through the growth of disulfide bridges which limits the development of reactive oxygen species associated with tissue injury while maintaining gastric integrity [35]. 
Hydrogen peroxide assay was further used to assess Trametes versicolor's antioxidant properties in the feed. The observed increase may be due to the presence of bioactive agents with antioxidant properties which helped to confer antiulcer properties on the fungus. This is in agreement with the findings of the Oyedemi et al. [36], that artificial and biological antioxidants were required to avoid negative effects of unpaired radicals.

The changes seen with the higher fungi supplemented feeds on Hydrogen/Potassium pump activities in the experimental rats could be attributed to antiulcer activity demonstrated by the test fungus. Trametes versicolor could have acted as gastric proton pump inhibitor. This is in agreement with the findings of Strand et al. [37] who reported that the primary goal of doctors when managing peptic ulcer is treating with drugs that promote proton pump inhibitor in order to reduce gastric acid secretion. The increase in mucin content may have conferred potential antiulcer properties on the Trametes versicolor supplemented diets by helping to maintain homeostasis through its mucosal defense system [38].

From the results obtained, it can be concluded that Tramates versicolor treatment groups demonstrated blood boosting and antiulcer activity at both concentrations through the synergistic activities of mucin, $\mathrm{H}^{+} / \mathrm{K}^{+}$ATPase activity, and antioxidant mechanism.

The results of this study suggest that diets enriched with Trametes versicolor do not contain the toxic effects that might hinder their therapeutic use as herbal medicine for the treatment of blood deficiencies and ulcer.

\section{REFERENCES}

1. Jonathan SG. Vegetative growth requirements and antimicrobial activities of some higher fungi in Nigeria (Doctoral dissertation, Ph. D thesis. University of Ibadan, Nigeria. 2002.

2. Gbolagade J, Ajayi A, Oku I, Wankasi D. Nutritive value of common wild edible mushrooms from southern Nigeria. Global Journal of Biotechnology and Biochemistry. 2006; 1(1): 16-21.

3. Otunla CA, Jonathan SG, Idowu OO, Olawuyi OJ. Mycelial growth and sclerotia production of Pleurotus tuber-regium (Fries) Singer on four sawdust types at three composting intervals. Agronomski Glasnik. 2018; 80(2): 79-90.

4. Chikwem J, Jonathan G, Hull A, Asemoloye M,Osonubi $\mathrm{O}$ and Omeonu F. Antimicrobial Potential of Trichaptum biforme and Bjerkandera adusta from Pennsylvania, USA. Journal of Natural Sciences Research.2020; 11(16): 1-8.

5. Jonathan SG, Fasidi IO. Antimicrobial activities of Lycoperdon pusilum (Bat. Ex.) and Lycoperdon giganteum (Pers.), Nigerian edible macro fungi. Afr. J. Biomed. Res., Nigeria. 2003; 6: 88-90.

6. Gbolagade JS, Fasidi IO. Antimicrobial activities of some selected Nigerian mushrooms. African Journal of Biomedical Research. 2005; 8(2): 83-7.

7. Gbolagade J, Kigigha L, Ohimain E. Antagonistic effect of extracts of some Nigerian higher fungi against selected pathogenic microorganisms. Amer-Eurasian Journal of Agricultural and Environmental Science. 2007; 2: 364-368

8. Jonathan SG and Awotona FE. Studies on Antimicrobial Potentials of three Ganoderma species. African Journal of Biomedical Research. 2010; 13(2): 119-125

9. Oluranti OO, Olawuyi OJ and Jonathan SG. Therapeutic properties of some Nigerian higher fungi. Nature and Science. 2012; 10(10): 135-143

10. Oluranti OO, Jonathan SG and Olawuyi OJ. Interactions of Extracts of Selected Macrofungi and Malaria Parasite, Plasmodium berghei berghei in BALB/c Strain Albino Mice. Journal of Scientific Research \& Reports. 2019; 23(3): 1-6

11. Chikwem J, Jonathan g, Hull A, Asemoloye M, Omuero R and Tanny PC. Comparative studies on antimicrobial potentials of Daedalea quercina and Tramates pubescens. IHE: Lincoln University Journal of Science. 2019; 8: 22-29.

12. Adeoye-Isijola MO, Olajuyigbe OO,Jonathan SG and Coopoosamy RM. Bioactive compounds in ethanol extract of Lentinus squarrosulus mont - a Nigerian medicinal macrofungus Afr $\mathrm{J}$ Tradit Complement Alternative Medicine. 2018; 15(2): $42-50$

13. Jonathan. Fungi Here, Fungi There, Fungi Everywhere: Unique and Unparalleled Contributions of Fungi to Environment, Food Production and Medicine-. Inaugural lecture. University of Ibadan. Ibadan. Nigeria; 91.

14. Oso BA. Mushrooms and the Yoruba people of Nigeria Mycologia. 1975; 67; 2: 311-319

15. Oso, BA. Pleurotus tuber-regium from Nigeria. Mycologia. 1977; 67(2): 271-277

16. Jonathan G, Chikwem J, Hull A, Abdul-Lateef N, Omuero R and Tanny PC. Antimicrobial activity of Pleurotus pulmonarius and Coprinus sterquilinus collected from Lincoln University campus. IHE: Lincoln University Journal of Science. 2019; 8: 14-21.

17. Kamiyama M, Urushihara M, Morikawa T, Konishi Y, Imanishi M, Nishiyama A, Kobori H. Oxidative stress/angiotensinogen/renin-angiotensin system axis in patients with diabetic nephropathy. International journal of molecular sciences. 2013 Nov; 14(11): 23045-62.

18. Janjušević L, Karaman M, Šibul F, Tommonaro G, Iodice C, Jakovljević D, Pejin B. The lignicolous fungus Trametes versicolor (L.) Lloyd (1920): a promising natural source of antiradical and $\mathrm{AChE}$ 
inhibitory agents. Journal of enzyme inhibition and medicinal chemistry. 2017 Jan 1; 32(1): 355-62.

19. da Cruz L, Dorn JD, Humayun MS, Dagnelie G, Handa J, Barale PO, Sahel JA, Stanga PE, Hafezi F, Safran AB, Salzmann J. Five-year safety and performance results from the Argus II retinal prosthesis system clinical trial. Ophthalmology. 2016 Oct 1; 123(10): 2248-54.

20. Addass PA, David DL, Edward A, Zira KE, Midau A. Effect of age, sex and management system on some haematological parameters of intensively and semi- intensively kept chicken in Mubi, Adamawa State, Nigeria. Iranian Journal of Applied Animal Science. 2012 Sep 1; 2(3): 277-82.

21. Aro SO, Ogunwale FF, Falade OA. Blood viscosity of finisher cockerel fed dietary inclusions of fermented cassava tuber wastes. InProc. of the 18th Annual Conf. of Anim. Sci. Assoc. of Nig 2013 (pp. 74-77).

22. Roy S. Clinical study of peptic ulcer disease. Asian Journal of Biomedical and Pharmaceutical Sciences. 2016; 6(53): 41-3.

23. Drini M. Peptic ulcer disease and non-steroidal anti-inflammatory drugs. Australian prescriber. 2017 Jun; 40(3): 91.

24. Ostry ME, O'Brien JG, Anderson NA. Field guide to common macrofungi in eastern forests and their ecosystem functions. Government Printing Office; 2011.

25. Dacie JV, Lewis SM. Investigation of abnormal haemoglobin and thalassaemia: Practical haematology. Edinburgh: Churchill Livingstone. 1994; 8: 249-86.

26. Inas ZA, Hala AK, Gehan HH. Gastroprotective effect of Cordia myxa L. fruit extract against indomethacin-induced gastric ulceration in rats. Life Sci J. 2011; 8(3): 33-45.

27. Elegbe RA, Bamgbose SO. Protective dietary factors in experimental ulceration-study of some Nigerian cereals and tubers. Postgraduate medical journal. 1976 May 1; 52(607): 258-63.

28. Varshney R, Kale RK. Effects of calmodulin antagonists on radiation-induced lipid peroxidation in microsomes. International journal of radiation biology. 1990 Jan 1; 58(5): 733-43.

29. Ronner P, Gazzotti P, Carafoli E. A lipid requirement for the $(\mathrm{Ca} 2++\mathrm{Mg} 2+)$-activated ATPase of erythrocyte membranes. Archives of Biochemistry and Biophysics. 1977 Mar 1; 179(2): 578-83.
30. Bewaji CO, Olorunsogo OO, Bababunmi EA. Comparison of the membrane-bound (Ca2++ $\mathrm{Mg} 2+)$-ATPase in erythrocyte ghosts from some mammalian species. Comparative Biochemistry and Physiology Part B: Comparative Biochemistry. 1985 Jan 1; 82(1):117-22.

31. Togun VA, Farinu GO, Oyebiyi OO, Akinlade JA, Ajibok HO, Olaniyonu BI. Comparative study of the effect of dietary replacement of $15 \%$ maize offal with pigeon pea (Cajanus cajan) grain or leaf meal on performance of weaners, rabbits. InProc of 32nd Annual Conf of the Nig Soc for Anim Prod 2007 Mar 18 (pp. 217-219).

32. Olorunnisola OS, Bradley G, Afolayan AJ. Acute and sub-chronic toxicity studies of methanolic extract of Tulbaghia violacea rhizomes in Wistar rats. African Journal of Biotechnology. 2012; 11(83): 14934-40.

33. Asemoloye MD, Chukwuka KS, Jonathan SG. Spent mushroom compost enhances plant response and phytoremediation of heavy metal polluted soil. Journal of Plant Nutrition and Soil Science. 2020 Aug;183(4): 492-9.

34. Moura Rocha NF, Venâncio ET, Moura BA, Gomes Silva MI, Aquino Neto MR, Vasconcelos Rios ER, De Sousa DP, Mendes Vasconcelos SM, de Franca Fonteles MM, De Sousa FC. Gastroprotection of ()- $\alpha$ - bisabolol on acute gastric mucosal lesions in mice: the possible involved pharmacological mechanisms. Fundamental \& clinical pharmacology. $2010 \mathrm{Feb}$; 24(1): 63-71.

35. Chandranath SI, Bastaki SM, Singh J. A comparative study on the activity of lansoprazole, omeprazole and pd- 136450 on acidified ethanoland indomethacin- induced gastric lesions in the rat. Clinical and Experimental Pharmacology and Physiology. 2002 Mar; 29(3): 173-80.

36. Oyedemi SO, Bradley G, Afolayan AJ. In-vitro and-vivo antioxidant activities of aqueous extract of Strychnos henningsii Gilg. African Journal of pharmacy and pharmacology. 2010 Feb 28; 4(2): 070-8.

37. Strand DS, Kim D, Peura DA. 25 years of proton pump inhibitors: a comprehensive review. Gut and liver. 2017 Jan; 11(1): 27.

38. Tulassay Z, Herszenyi L. Gastric mucosal defense and cytoprotection. Best Pract Res Clin Gastroenterol. 2010; 24(2): 99-108. 